\title{
ARE INNOVATION AND INTERNATIONALIZATION INTERTWINED? A QUANTITATIVE STUDY OF THE IMPACT OF THE TYPES OF PROGRAMS IN ELITE BUSINESS SCHOOLS
}

\author{
Kaltenecker $\mathrm{E}^{1^{*}}$ and Okoye $\mathrm{K}^{2}$ \\ ${ }^{1}$ EGADE Business School, Tecnológico de Monterrey, México \\ ${ }^{2}$ Writing Lab, Institute for Future of Education, Office of the Vice President for Research \\ and Technology Transfer, Tecnologico de Monterrey, Monterrey, CP 64849, Nuevo Leon, \\ Mexico
}

\begin{abstract}
Although relevant pieces of literature discuss innovation in management education and the importance of internationalization of business schools, there is a lack of scholarly articles analyzing the mutual influence between internationalization and innovation in business schools, particularly when considering the types of programs and their location. Henceforth, to fill the identified theoretical gap, this article pursues the following research question: Are innovation and internationalization intertwined in elite business schools? The study follows a two-step methodology in its investigation and experiments. First, we performed a correlational analysis using linear regression (OLS) to determine if there is a relationship between internationalization and innovation of business schools by considering two types of programs: the Global MBA, and the Executive MBA. The results of the OLS method show that there is no correlation between Innovation and Internationalization in the Global MBA programs $(p=.546)$ whereas, there exists a positive correlation between Innovation and Internationalization in Executive MBA $(p=.00)$. Second, we conducted a One-way multivariate analysis of variance (MANOVA) to evaluate the impact of the location of the MBA programs on internationalization and innovation. We found that location presented no significant relationship with internationalization and innovation in the Global MBA program (as their significance levels were $p=.483$ and $p=.490$, respectively) and Executive MBA programs ( $p=.222$ and $p=.654$, respectively). In both cases, these results mean that internationalized or highly innovative programs such as Global MBA and Executive MBA programs can be found all over the world. Thus, we reached two main sets of conclusions. First, innovation and internationalization are uncorrelated in Global MBA programs, whereas both variables (innovation and internationalization) are correlated in Executive MBA programs. For the second set of conclusions, we note that the location of business schools does not impact their internationalization and innovation.
\end{abstract}

Keywords: Educational Innovation, Internationalization, Executive Education

\section{Introduction}

Innovation and Internationalization are particularly relevant themes for business schools and their programs to train global managers. Traditionally, advanced business education provided by Executive programs has been dependent on how innovative the programs are, e.g., in terms of formats (short vs long duration, remote vs. classroom, blended vs. traditional), and use of technology (augmented 
reality, data analytics, artificial intelligence, etc.). This also includes how global are the programs in terms of the geographical origin of the faculties and participants, geographical dispersion of campuses, and understanding of regional idiosyncrasies of multinationals and countries in the diaspora.

There are relevant pieces of literature both in terms of innovation and internationalization of traditional firms in general (Iandolo \& Ferragina, 2019) and business schools in particular (Schlegelmilch 2020). On the one hand, Zhu (2015) surveyed six universities to analyze the impact of organizational culture and technology in innovation in higher education. Whereas, Sharif \& Tang (2014) assessed the collaborative activities in innovation by focusing on knowledge transfer between university research facilities, research institutes, industry, and government. Hura (2013) argues that the need for innovation forces executive education and MBA programs to respond with flexibility. More recently, Schlegelmilch (2020) discussed the need for radical transformation through the innovation of business schools. On the other hand, regarding internationalization, the survey by Bennett \& Kane (2011) transpired that the degree and/or speed of internationalization within business schools appeared to depend significantly on several factors, such as the financial situation of the university, managerial inclinations favoring internationalization, financial dependence on foreign students, desire to attract greater numbers of students from overseas, size of the business school, age of its host university, and the belief that an internationalized curriculum is capable of improving employment. Moreover, Youssef, Bygholm \& Jaeger (2012), discussed the difficulties of internationalization of business schools and concluded that the use of blended learning models of teaching and advanced distance learning technologies is not enough to overcome the barriers that arise in countries that tend to significantly differs from the country of origin of the business school.

However, even though the aforementioned relevant pieces of literature presents the need for innovation in management education courses and the importance of internationalization of business schools, we note that there is a lack of scholarly articles analyzing the mutual influence of the varying levels of internationalization and the innovation status on business schools, particularly when considering the geographic distribution of the said schools and the offered programs in executive education. Henceforth, to fill the identified theoretical gap, this article pursued to address the following research question: Are innovation and internationalization intertwined in Elite Business Schools?

The rationale of the study follows a two-step methodology to address the research question. In the first round, a linear regression analysis was performed to understand the correlation between internationalization and innovation of two defined types of MBA programs (Global MBA and the Executive MBA) offered by the business schools. To do this, we evaluated data about the rankings published by the Financial Times (Business Education, 2020). The data includes information about the Global MBA and the Executive MBA programs. In the second round, we determined the impact of the Location of the aforenoted business schools in terms of their internationalization and innovation levels. We performed the analysis using a One-way multivariate analysis of variance (MANOVA) test to establish the effect that the location (predictor variable) has on the Internationalization and Innovation (response variables), respectively. For the third and final step, a pairwise comparison and Post Hoc (Tukey HSD) tests were used to determine where the significant differences lie by 
considering the Location (country of origin) of the business schools and the levels of their innovation and internationalization, respectively.

The rest of the manuscript is divided into different sections. Part Two presents a review of the literature about the executive education and/or industry concerning innovation and internationalization in management education programs. Part Three describes the methodology, data sampling, and the constructs utilized in this study. Part Four presents the data analysis and results, which are described in detail in Part Five. The discussion of the research outcome is presented in Part Six, while Part Seven concludes and presents the implications of the study for practice.

\section{Literature Review}

\section{The evolution of business schools}

Business schools manifest many of the attributes of a classic professional services firm, such as high labor content, high customization of activities, high customer contact, and the delivery of knowledgeintensive services dependent upon expert talent (Haskins, Hicks \& Centini, 2020). More specifically, the delivery of executive education is an important part of business schools because it provides prestige, and financial contribution to the institutions, in addition to the creation of the much-needed knowledge in management, to differentiate from the many courses available worldwide.

From an evolutionary perspective, there are three distinct periods in the evolution of programs of management education. The first phase occurred before the 1950s, mainly in the United States of America. During that period, the approach was very functional and most business professors were practitioners or retired corporate managers, whose focus was to train students in business lessons. Moreover, because corporations and their current/retired employees contributed so much as teachers and participants to set the MBA agenda, the aforementioned period was called the "Corporate-Based Era" (Friga, Bettis, \& Sullivan, 2003).

The second phase started during the 1950s and finished around the end of the $20^{\text {th }}$ century. This phase was marked by an increasing professionalization of the faculties, the use of $\mathrm{PhD}$-trained professors, the rise of MBA rankings, and the start of competition in regional levels (e.g. the USA vs. Europe). This period also featured the emergence of many new courses such as the Customized and Open Enrollment Executive MBA programs. Moreover, the said programs consisted of traditionally offered courses in business topics such as Strategy, Finance, Marketing, Operations, and Organizational Management. In this phase, the main source of the creation of knowledge was research in managerial topics. It is important to also note that the rise of ranking systems for business schools forced them to be more proactive in making changes (Friga, Bettis, \& Sullivan, 2003).

The third phase of the programs in executive education started in the $21^{\text {st }}$ century. The MBA programs of this phase fostered the capacity of the students to integrate various functional perspectives to meet the complex business challenges of the new century. This skill, called "integrative thinking", refers to the capacity of taking a cross-functional, multidisciplinary approach to provide solutions for unstructured problems. Indeed, to facilitate the acquisition of the said skills, business schools need to reposition themselves to face the changing nature of business around the world. Among many fronts in which the repositioning of executive programs may happen, there is the rise of digitization of processes and the use of Industry 4.0 tools (Kaltenecker, Kahle-Piasecki, 2019), innovation and 
internationalization Corporate Social Responsibility (CSR), and the emergence of consulting projects (Lockhart, 2013). The third wave of executive education also witnessed the use of managerial knowledge by non-profit sectors, such as governments and Non-Governmental Organizations (NGOs).

The rise of the ranking system is a characteristic of the second phase of the evolution of business schools. Most of the existing media firms that specialize in global finance and economy publish regularly rankings featuring the best graduate programs in executive education, and the most relevant ones are Financial Times, Forbes, Bloomberg, The Wall Street Journal, and The Economist. Although each ranking system represents its methodology and/or approach, the criteria used to rank the business schools tend to measure some of the same characteristics, such as percentage of international faculties, percentage of international students, the impact of the research developed by the faculty, the design of the programs, and teaching methods and materials, to name a few.

The increasing use of rankings forced the programs within the executive education sector to focus on specialization or in a niche in the marketplace. Whereby, fragmentation is a consequence of strategic decisions taken by the different programs to compete in different dimensions. In turn, no business school has a clear, dominant position in the executive education segment (Lloyd \& Newkirk, 2011). Interestingly, as the market for education in management became increasingly crowded and competition between the programs intensified, the business schools pursued differentiation strategies in innovation and internationalization (Narayandas, 2007, Hawawini, 2011). For instance, Guillotin (2015) argues that non-elite business schools relied on internationalization to avoid being commoditized by the Massive Open Online Course (MOOC) phenomenon.

Guillotin and Mangematin (2015) contributed to the research international expansion of business schools by discussing the internationalization path of business schools. The authors pointed out that such institutions are spreading fast around the world to satisfy the global demand for education. Business schools' goal is to create and disseminate knowledge to prepare managers for the global market. On the other hand, Harrison, Leitch, \& Chia (2007) analyzed innovation in business school, through the offering of fresh insights, counterintuitive interpretation, and radical alternatives to reallife problems that stands as the competitive advantage of university-based business schools over corporate universities, management training institutes, and consultancies. The support from the literature review leads this article to focus on the analyzes of the internationalization and innovation of executive education programs in business schools.

The following sections, Are Innovation and Internationalization connected? Why and How?, Innovation in the Management Education Industry and Internationalization in the Management Education Industry present a review of the literature that supports the analysis of innovation and internationalization of the different programs in management education.

\section{Are Innovation and Internationalization connected? Why and How?}

Literature in management shows that the internationalization of firms and their innovation processes are interlinked. Specifically, the literature generally supports a positive relationship between internationalization and firms' innovation (Tsao, Chen, 2012). Chetty \& Stangl (2010), when analyzing the dynamics of network relationships, affirm that firms with limited network relationships 
have incremental internationalization and innovation, but those with diverse network relationships have radical internationalization and innovation, a finding that indicate that network relationships are influential in shaping the firm's future. The work of Roper \& Love (2002) confirms that innovation confers market power, and as a consequence, facilitates internationalization. While Boermans \& Roelfsema (2015), in their study about firms from transition economies, found that internationalization causes higher levels of innovation. Additionally, Zahra et al., (2000) found that multinational firms, such as many international business schools, can obtain a competitive advantage through the integration of innovation that arises from geographically widespread facilities. Innovation and internationalization are possibly associated with a virtuous cycle, in which internationalized firms are exposed to a more competitive environment that requires more innovation, thus increasing the competitive level of a firm (Filippetti, Ietto-Gillies, 2011). This analysis confirms the reciprocal interactions between innovation and internationalization discussed by Chiva, Ghauri, \& Alegre (2014). In some industries, notably the high-tech one, internationalization is compulsory if it is to stay in business schools or organizations because a firm producing innovative products has only a few (if any) potential domestic clients (Saarenketo, 2004). Kafouros, Buckley, Sharp, and Wang (2008) go further to claim that firms need to be active in many markets, i.e., to be internationalized to capture the benefits of innovation. A dynamic perspective of the internationalization-innovation relationship was added by Altomonte, Aquilante, Békés, \& Ottaviano (2013), who believes that in the medium-tolong term, internationalization is driven by innovation. More recently, and specifically with management programs, Guillotin (2018) proposed internationalization as a way to increase enrollments by leveraging curriculum innovation and stakeholder engagement. In summary, evidence from the literature review supports the existence of a relationship between internationalization and innovation. Why does this relationship exist? Because of a strong mutual dependence between the two constructs. How these two constructs interact? Through a very multi-disciplinary nature, as recently confirmed by Vrontis \& Christofi (2019).

\section{Innovation in the management education industry}

Innovation is referred to as a differentiation strategy due to the increasing number of non-innovative offers that have become common within the management education industry. Innovation became a differentiation strategy because many executive programs are abridged versions of traditional MBA courses. Therefore, top-ranked programs are the ones that shifted from being teacher-centered to learner-centered, and from general case studies to real-life problems faced by the firms (Conger and Xin, 2000). Additionally, a shift towards customization and action-learning projects became the norm because the said programs in question are now tailored to individual companies or consortiums of companies. Specifically, Latham, Latham, \& Whyte (2004) make a differentiation between the Executive and the MBA programs. In other words, whilst the former is customer-driven and uses an integrated approach to learning, the latter is subject-driven and participants' learning experience is divided into blocks/subjects such as Finance, Marketing, HR, and Strategy, etc. Moreover, both increase in competition and customer demands for relevance, are forcing business schools to rethink traditional approaches and consider (more) new integrative approaches to teaching business marketing and sales to executives (Narayandas, 2007).

Furthermore, compelling research and development (R\&D), as well as thought leadership, are not only drivers but also competitive advantages of innovation in management education. Besides, the use of delivery methods other than the traditional case methods is also an example of innovation in 
management programs (Büchel, Antunes, 2007). Stoten (2018) suggests that there is significant innovation and diversity within British business schools while Navarro (2008) counter-argues that there is a lack of product differentiation (in other words, innovation) in the MBA Core Curricula of Top-Ranked U.S. Business Schools. More recently, Schlegelmilch (2020) strongly advocated the adoption of radical innovation in business schools.

\section{Internationalization in the management education industry}

The historical international nature of universities plays out in new dynamic ways by pushing these institutions to pursue new market opportunities in the host countries. Moreover, like any multinational companies, business schools internationalize to internalize knowledge obtained in the host countries (different consumer behavior, business models, and regulatory frameworks), as previously addressed by da Silva Lopes, Casson \& Jones (2019), and Narula, Asmussen, Chi \& Kundu (2019). Moreover, the globalization of markets including that of the educational sector has brought a new challenge for business schools (Altbach, Reisberg, Rumbley; 2019). In the case of executive education, as many companies internationalize and face global competition, students and employers demand a solid international education in management. In response, most business schools have adapted their organizational structure, and geographic dispersion to be international. Using two analytical dimensions, location of delivery and the origin of the students, Engwall \& Kipping (2013) proposed four mechanisms of internationalization of higher education: Import of ideas (knowledge imported through international research networks and business school models and templates), Outsourcing (internationalization through the mobility of people), Insourcing (internationalization through international student and/or faculty, delivered in the home country), and Foreign Direct Investment (FDI), internationalization through investment abroad requiring the highest level of commitment, and representation of the highest financial and reputational risks, delivered in the host country. Although the high-level risks associated with this strategy, Silvanto, Ryan, \& Gupta (2017) suggests they are worth because leading business located in economically globalized locations schools offer greater levels of international experiential learning students. Hawawini (2011) proposed five models of internationalization of executive education programs.

a) The import model, which attracts students and faculty from around the world to the institution's campus. In this case, importers maximize the chance of direct interactions and cross-cultural learning. This model has an intrinsic limitation: a campus populated with foreign students and faculty is unlikely to provide the equivalent of the international experience students and faculty would gain had they been physically living, working, and studying in other countries.

b) The export model, which consists of sending abroad faculty and students. The faculties deliver courses off-site but the school's original campuses remain at the center of the entire system. These off-site courses are usually located in the host country and may include students from the original campuses. This model exposes students and faculty to other countries and cultures to enrich their knowledge and experience. In general, successful exchange schemes have a limited number of partners who work closely together around a program that does not involve a large number of students and faculty.

c) Academic joint-ventures, which consists of student-exchange programs, offering participants in the courses the possibility of having classes in the foreign institution. This mode may evolve into 
academic or curricular joint ventures in which institutions located in different countries design and deliver joint programs, with graduates receiving either a single co-signed degree or two separate degrees.

d) Academic partnerships, alliances, and consortia, which consist of two or more business schools forming broader international partnerships to collaborate on several initiatives such as student and faculty exchanges, joint programs, and faculty research. Common research funds are created to support research projects carried out by teams of faculty members from both institutions. The partnership can also enter into academic joint ventures to create new joint programs.

e) Campuses abroad, which consists of extending their international reach through a physical presence, like the direct foreign investment of firms, by establishing full-fledged campuses abroad in which temporary or permanent faculty and staff are posted and where local or international students attend a variety of courses throughout the year. Campuses in foreign countries are the ultimate form of internationalization of business schools. Such units generate knowledge that will influence the original campus, an issue confirmed by da Silva Lopes, Casson \& Jones (2019)

It is important to note that not every executive education program evolves into the Campus model. This happens because some schools are small, do not have the resources to become global, or are simply focused on an attractive regional market. Additionally, for some business schools, the right strategy or option is to become a center of excellence in functional areas such as finance, corporate governance, and digital marketing, for example. Finally, the models of internationalization are not mutually exclusive. For example, leading business schools not only send abroad some of their mostrenowned faculty to undertake executive programs in major cities around the world but also host the executives from their associated global corporate clients to receive proper training in management on the main campuses.

\section{Location (country of delivery) in the management education industry}

On the one hand, the international expansion of multinationals firm can be analyzed through the framework of the Ownership-Location-Internalization paradigm (Dunning, 2015), which describes the ownerships advantages (0), which include the assets, tangible and intangible that the institution possesses but that its competitors do not possess, the location advantages (L), which explain where multinationals expand their business to, and internalization advantages (I), which explain how firms organize the scope and mode of their international activities, to take advantage of the O- and Ladvantages (Zhou, \& Guillen 2016). In regards to the L-advantages, they are not the same for all business schools because elite programs are very sensitive to location-specific problems that may undermine their brand legitimacy, while non-elite schools are more vulnerable to overestimating the attractiveness of the location and inability to transfer their proof of quality to the host-country market (Alajoutsijärvi, 2019). Therefore, location matters differently for different business schools. The analysis of Juusola, Kettunen, \& Alajoutsijärvi (2015) supports that the internationalization of business schools in general, and the L-advantages in particular, follow two logics. First, the academic logic, which explains why elite schools are sensitive to possible failures that may damage their internationally recognized brand. Second, the market logic that drives cross-border activities because of the size of the market (number of qualified prospective students). 
On the other hand, the literature about location and innovation presents some correlations between these two topics. Ervits (2020) addresses the geographical dimension of cross-border knowledge integration and investigates the patterns of international co-invention or the links between headquarters and the firm's subsidiaries. Ferreira, Fernandes \& Raposo (2017) confirmed that the greater the geographic proximity of a company to urban centers (where most business schools are located), the greater their capacity to innovate.

\section{Types of Programs in Executive Education}

This paper focuses on the two main types of programs in executive Education: The Global MBA and the Executive MBA. First, Global MBA is a degree-granting, full-time program that follows academic calendars, semester courses, grade point evaluation, etc. (Friga, Bettis \& Sullivan, 2003; Latham, Latham \& Whyte 2004). The Global MBA programs require a high commitment of time from the participants because the courses last from one to two academic full years and the admission process is very selective for the top-ranked programs, which tend to attract middle-level managers wanting to move to a different business unit, targeting senior positions in large multinationals or to open new companies, such as technology-based start-ups. Additionally, the traditional Global MBA program attracts participants with modest work experience (Gregg, Stewart, 2013). Second, is the Executive MBA, which is a non-degree program that attracts senior managers with a solid managerial background. The Executive MBA modules tend to be largely part-time, requiring mid-level time commitment from the participants, and are, in general, abridged versions of full-time MBA programs. The participants in such courses pursue very senior positions in their respective companies because, in some firms, the type of education the executives receive during the Executive MBA programs is a requirement for the next career level.

The following section - Methodology - presents the methodological approach used in this research, the source of data utilized for this study, and the constructs we considered for the analysis and conclusions.

\section{Methodology}

\section{Data Source and Sampling: Financial Times rankings}

The source of data for this research was $\mathrm{f}$ the 2017 to 2019 rankings provided by the Financial Times (Business Education, 2020). The Financial Times is an English-language international daily newspaper headquartered in the UK, with a special emphasis on business and economic news. Our criteria for selection of the Financial Times rankings (FT) is based on the relevance of the source due to its FT's influence and prestige in the business segment, its global perspective (a critical topic in the evaluation of internationalization of executive programs), the consideration of main factors such as innovation and internationalization in their rankings, and the experience gained by the publisher following the fact that the institution has published rankings of several programs since 1999. Although there are other rankings available, they were not used in this research because they focused on factors that cannot be used to compare or evaluate the correlation between Internationalization and Innovation. For example, the Bloomberg Best Business Schools ranking evaluates Compensation, Learning, and Networking (Best B-Schools Rankings 2019-2020), the QS Global MBA Rankings uses Entrepreneurship \& Alumni Outcomes, Return on Investment, Thought Leadership, and 
Employability in its analysis (QS Global MBA Rankings 2020,2019), The Forbes Full-time MBA ranking compares graduates' earnings in their first five years after getting their M.B.A to their opportunity cost to arrive at a five-year M.B.A gain (Badenhausen, K., \& Settimi, 2019). The MBA ranking from The Economist magazine uses criteria such as Student quality, Education experience, Percentage increase on pre-MBA salary vs Post-MBA salary, Potential to network, Breadth of the alumni network, and Student rating of alumni effectiveness (Full-Time MBA Ranking, 2020), which are not relevant to the objectives of this research. Statistically, we used a total sample of $n=200$ data about the different B-schools to conduct the data analysis and experimentations in this paper. This includes $n_{1}=100$ for Global MBA and $n_{2}=100$ for Executive MBA.

\section{Constructs for Innovation and Internationalization}

To evaluate the correlation between Innovation and Internationalization in the top-ranked B-schools, we took into consideration the performance indicators in the data that dealt with innovation and internationalization for each of the programs. The average of 2017, 2018, and 2019 was used for each indicator. Based on the self-explanatory definitions of each indicator, the constructs were created for each of the four types of programs we analyzed.

For the Global MBA and Executive MBA rankings, the Innovation construct was built with the data from the Financial Times Research rank because of its source of new knowledge, and Financial Times Corporate Social Responsibility (CSR) rank because of its important topic in the third phase of the evolutionary process of business schools and a differentiating topic among business schools, according to Lilley, Barker, \& Harris (2014), Schlegelmilch \& Thomas (2011), Mayes, Bracey, Aguilar \& Allen (2015), and Christensen, Peirce, Hartman, Hoffman \& Carrier (2007). On the other hand, the Internationalization construct was built taking into consideration the FT's data about the percentage of International faculty, percentage of international students, percentage of international board members, international mobility rank, and International course experience rank. Table 1 provides the criteria we used to build the constructs for innovation and internationalization for each of the two programs.

Table 1: Types of programs and the constructs for innovation and internationalization

\begin{tabular}{|c|c|c|}
\hline Programs & $\begin{array}{l}\text { Data used to create the construct } \\
\text { "Innovation" }\end{array}$ & $\begin{array}{l}\text { Data used to create the construct } \\
\text { "Internationalization" }\end{array}$ \\
\hline Global MBA & $\begin{array}{l}\text { Financial Times Research rank } \\
\text { Corporate Social Responsibility } \\
\text { rank }\end{array}$ & $\begin{array}{l}\% \text { of International faculty } \\
\% \text { of International students } \\
\% \text { International board } \\
\text { International mobility rank } \\
\text { International course experience } \\
\text { rank }\end{array}$ \\
\hline Executive MBA & $\begin{array}{l}\text { Financial Times Research rank, } \\
\text { Corporate Social Responsibility } \\
\text { rank }\end{array}$ & $\begin{array}{l}\% \text { of International faculty, } \\
\% \text { of International students } \\
\% \text { International board } \\
\text { International course experience } \\
\text { rank }\end{array}$ \\
\hline
\end{tabular}




\section{Data analysis and Method implementation}

As defined in the method description, we followed a two-step methodology to address the research question. In the first round of analysis, we performed a correlational analysis using the linear regression (OLS) method to determine if there is a relationship between Internationalization and Innovation of business schools (B-schools) by considering the two types of programs in executive education: the Global MBA, and the Executive MBA. For this analysis, the independent (predictor) variable was Internationalization, and the dependent (response) variable was Innovation. The result of the method is as reported in Table 2 and explained in detail in the data analysis and results section.

Furthermore, for the One-Way MANOVA analysis, we first checked if the data violates the assumptions of normality ( $p>.05)$ using the Kolmogorov-Smirnov and Shapiro-Wilk tests for normality. Given that a majority of the variables were considered normal when analyzing the four sets of data, and for the fact that considering the validity of the data sample; Roscoe's rule of thumb notes that the sample size limit for conducting research experiments should not be less than 30 (parameters) participants (Roscoe, 1975). Along these lines, we applied the One-Way MANOVA test since the sample size (the two types of programs we analyzed) used for this analysis ( $n_{l}=100$ for Global MBA and $n_{2}=100$ for Executive MBA) is considered to be large and adequate (i.e. $\mathrm{n}>30$ ) (Roscoe, 1975; Lee Rodgers, Nicewander, 1988; Chin, Lee, 2008).

Thus far, in the second round of analysis (i.e., One-Way MANOVA) we evaluated the impact that Location (i.e., the geographical distribution of the B-schools) has on the internationalization and innovation of Global MBA and Executive MBA Programs. For this analysis, the independent variable was the Location and the dependent variables were internationalization and innovation. The result of the method is as reported in Table 3 and explained in detail in the data analysis and results section.

\section{Results}

\section{Results from the First Round of Data Analysis}

The results of the correlation analysis between Innovation and Internationalization for the different programs, as reported in Table 2, shows that there is no positive correlation between Innovation and Internationalization in the Global MBA programs. Whereas, there exists a positive correlation between Innovation and Internationalization in the Executive MBA.

Table 2: Linear Regression (OLS) Correlation analysis for Internationalization vs. Innovation

\begin{tabular}{lll}
\hline Type of Program & F & p-value \\
\hline Global MBA & .367 & .546 \\
\hline Executive MBA & 28.474 & $0.00^{*}$ \\
\hline Note: significant levels: $\mathrm{p}<=0.05$ & \\
\hline
\end{tabular}

\section{Results from the Second Round of Data Analysis}

The results of the One-way Multivariate Analysis of Variance (MANOVA) helped us to understand the impact of Location (i.e., the geographical distribution of the business schools) on 
internationalization and innovation for the two types of executive education programs as presented in Table 3. We found that for both the Global MBA and the Executive MBA programs, Location (the independent variable) has no impact on the internationalization and innovation (the dependent variables), as there is no significant effect ( $p<=.05)$ between the variables. Thus, with Global MBA internationalization $p=.483$, and Innovation $p=.490$.

Table 3: One-Way MANOVA results for impact of Location (IV) against Internationalization \& Innovation (DV)

\begin{tabular}{llllll}
\hline Location & Dependent Variable & $\begin{array}{l}\text { Mean } \\
\text { Square }\end{array}$ & F & Sig. & $\begin{array}{l}\text { Partial Eta } \\
\text { Squared }\end{array}$ \\
\hline $\begin{array}{l}\text { Global } \\
\text { MBA }\end{array}$ & Internationalization & 23.103 & .826 & .483 & .025 \\
\cline { 2 - 6 } & Innovation & 308.521 & .813 & .490 & .025 \\
\hline $\begin{array}{l}\text { Executive } \\
\text { MBA }\end{array}$ & Internationalization & 137.413 & 1.491 & .222 & .045 \\
\cline { 2 - 6 } & Innovation & 127.703 & .543 & .654 & .017 \\
\hline Note: significant levels: $\mathrm{p}<=0.05$ & & & & \\
\hline
\end{tabular}

\section{Discussion of the results and outcomes}

\section{Discussion of the first round of analysis}

The first topic to be discussed is the different correlations between innovation and internationalization in the two programs. We believe that the idiosyncrasies of each program, such as the academic demand, duration, and level of experience of the participants explain the non-uniformity of the results. Surprisingly, the only course that did not present a correlation between internationalization and innovation was the Global MBA, the centerpiece of management education (Tan \& Ko, 2019). Therefore, MBA programs for the elite business schools seem to have either changed little (limited innovation) or not globalized sufficiently (limited internationalization) despite substantial changes both in the practice of business and in the claims made by business schools. The first explanation for this apparent illogic outcome is a possible conservative approach from deans and academic leaders responsible for the Global MBA programs. Due to the importance of this program in the reputation of the business schools, these institutions have limited incentives to take risks and, as a consequence, do innovate significantly the curricula of their most important academic offer, an evaluation confirmed by Walsh \& Powell (2020), who suggested the inclusion of a wider range of knowledge to keep the relevance of MBA programs. Second, the background of the business professors, largely researchoriented, creates a superior class on the methodology and scientifically-oriented research, not necessarily perceived as innovative by the participants of the MBA programs. Therefore, although the Global MBA programs are internationalized in terms of diversity of students, faculty, and sometimes in the number of locations of international modules, the programs are not necessarily innovative in terms of delivery methods, and content. Finally, two-year long MBA programs are longer than the other types of executive programs, which probably verges to make them less flexible to innovate.

The second conclusion comes from the correlation we found between Innovation and Internationalization in the Executive MBA programs, as in this case, the p-value of these correlations was significant $(\mathrm{p}=.00)$ (Table 3). The result can be attributed to several factors. First, the highly competitive scenario of the executive education industry where such top-level programs, i.e., the ones 
included in the FT rankings, compete with each other on a global basis for their sophisticated global customers, which are multinationals companies in need of providing specialized (expert) training for their executives. Also, given the fact that these multinational companies can compare a large pool of programs in management on a global scale; competition between the programs is based on differentiation, which leads to innovation. Second, the modules for the Executive programs are shorter than the ones for the full-time MBA programs, therefore, changes in the executive programs are easier to implement, evaluate, and even more implement new changes, when necessary. Third, the faculties in the executive programs are more diverse, as these modules invite not only research-oriented faculties, but also high-level executives and practitioners (CEOs, for instance), consultants, journalists, and guest speakers with diverse backgrounds, such as journalists, athletes, and even media celebrities. Finally, the very nature of such type of customized programs requires business schools to design and deliver customer-and-project-specific solutions on a very frequent basis. As a consequence, the executive programs differ from each other not only because they were offered by different business schools, but also because they were designed and delivered to fit specific demands from different global customers. Therefore, innovation and internationalization are tightly connected and are intrinsic parts of the business of education in management in this setting. Besides, the managerial implication is that both innovation and internationalization are, inevitably, required responses to the cutthroat business environment of this demanding sector, an idea already discussed by Schlegelmilch (2020). Consequentially, the first round of analysis addresses partially the research question: Are innovation and internationalization intertwined in elite business schools? Regarding the types of academic offers, the answer is yes, but now for all programs. Surprisingly the main program, the MBA, shows no correlation between Internationalization and Innovation.

\section{Discussion of the second round of analysis}

The second round of analysis focused on understanding the impact of the country of origin (the independent variable) on internationalization and innovation (the dependent variables) of the four types of programs using the MANOVA method. Once again, the impacts of location in internationalization and innovation differ according to the types of programs. On the one hand, for the MBA and Executive MBA programs, the country of origin of the business schools does not affect their internationalization and innovation, a very surprising result due to the leadership, experience, brand, sizes of both student class and faculty, alumni clubs and first-mover advantage of the North American and then European business schools. On the other hand, for the executive education open and customized programs, the country of origin affects their internationalization and innovation.

The quite surprising lack of effect of the country of origin in the internationalization and innovation of the MBA programs can be attributed to: (i) the internationalization modes used in these types of programs, and (ii) the duration of these programs. Many MBA and Executive MBAs from elite business schools are delivered primarily in the main campus of these institutions (the import mode) and secondarily during in locations around the world, (export mode) through campuses from other programs and visits to local companies. This argument is backed by Hawawini (2011), who presented the limitations of these internationalization modes because they bring limited international experience for the institution and participants. Therefore, MBA and Executive MBA programs present limited country of origin effects regarding internationalization because of the limitations of the internationalization modes used in these programs. In the case of the executive education open 
enrollment and customized programs, the influence of country of origin in the internationalization and innovation takes place as expected, because most elite business schools are based in the United States and Europe. Consequentially, the second round of analysis addresses partially the research question. Are innovation and internationalization intertwined in elite business schools? Regarding country of origin effects, no for the MBA and Executive MBA programs, but yes for the executive education open and customized programs. However, there is no information about which geographic location is more impactful than the others, which is answered in the final round of analysis.

\section{Conclusions and Implication for Practice}

The first round of analysis showed that the Global MBA programs are the only type of courses with no correlation between internationalization and innovation. This result shows that the leaders or heads of Global MBA programs tend to be conservative. In case program managers want to achieve innovation and internationalization simultaneously, they may need to make use of different modes of internationalization and add different types of faculty, such as experienced practitioners and CEOs, and artists, for instance, from different countries. This conclusion aligns with Laud \& Johnson (2013), whose research provides support to the growing concern that managerial and behavioral skills education has been overshadowed by the quantitative orientation emphasized in most MBA programs, a characteristic that Lockhart (2013) calls the academic-practitioner divide. This recommendation also lines up with Dover, Manwani, \& Munn, D. (2018). who suggested that modern, visionary business school will evolve into a networked entity (inside and outside the academic fraternity), conducting cutting-edge, thought leadership research undertaken by cross-functional and often cross-institutional teams.

The second round of analysis shows that "Location does not Matter" because it does not impact the MBA and Executive MBA programs. As a consequence, leaders of such programs from different parts of the world will need different actions or strategies if they want to increase innovation and internationalization. Although, we note that for these programs, there is no "one size fits all" action to take. However, the question of which regions favor innovation and internationalization remains an open phenomenon.

Finally, an important conclusion and implication for practice derived from the analysis of the results in this paper, is that all of the business schools were based on a sample of programs collected from amongst the best 100 programs in the world, delivered from sophisticated, resourceful, well-known business schools that are already more innovative and internationalized than the average business schools around the globe. Moreover, the recommendations in this study were focused or based on programs whose goals move to (or stay in) the top programs worldwide.

This study presents some limitations, which is an opportunity for future research. This manuscript analyzed elite business schools, which were sophisticated, resourceful, and globally-known institutions. The results may differ for non-elite business schools.

\section{Acknowledgment}

The authors would like to acknowledge the technical and financial support of Writing Lab, Institute for Future of Education, Tecnológico de Monterrey, in the publication of this work. 


\section{References}

Alajoutsijärvi, K. (2019). Revisiting Dubai's Business School Mania. Academy of Management Learning and Education, 18(3).

Altbach, P. G., Reisberg, L., \& Rumbley, L. E. (2019). Trends in global higher education: Tracking an academic revolution. Brill.

Altomonte, C., Aquilante, T., Békés, G. and Ottaviano, G. I. (2013). "Internationalization and innovation of firms: evidence and policy”. Economic policy, Vol. 28 No. 76, pp.663-700.

Badenhausen, K., \& Settimi, C. (2019). "The Best Business Schools 2019”. Available at: https://www.forbes.com/business-schools/\#1bb8c8876d6d (accessed Sept. 2020)

Büchel, B., \& Antunes, D. (2007). Reflections on executive education: The user and provider's perspectives. Academy of Management Learning \& Education, 6(3), 401-411.

Chetty, S. K., \& Stangl, L. M. (2010). Internationalization and innovation in a network relationship context. European Journal of Marketing.

Chiva, R., Ghauri, P., \& Alegre, J. (2014). Organizational learning, innovation and internationalization: A complex system model. British Journal of Management, 25(4), 687-705.

Conger, J. A., \& Xin, K. (2000). Executive education in the $21^{\text {st }}$ century. Journal of Management Education, 24(1), 73-101.

Chin, R., \& Lee, B. Y. (2008). Principles and practice of clinical trial medicine. Elsevier.

Christensen, L. J., Peirce, E., Hartman, L. P., Hoffman, W. M., \& Carrier, J. (2007). Ethics, CSR, and sustainability education in the Financial Times top 50 global business schools: Baseline data and future research directions. Journal of Business Ethics, 73(4), 347-368.

da Silva Lopes, T., Casson, M., \& Jones, G. (2019). Organizational innovation in the multinational enterprise: Internalization theory and business history. Journal of International Business Studies, 50(8), 1338-1358.

Dover, P. A., Manwani, S., \& Munn, D. (2018). Creating learning solutions for executive education programs. The international journal of management education, 16(1), 80-91.

Dunning, J. H. (2015). The eclectic paradigm of international production: a restatement and some possible extensions. The eclectic paradigm, 50-84.

Ervits, I. (2020). R\&D by US multinationals in China: geography and patterns of co-invention. International Journal of Emerging Markets.

Ferreira, J. J., Fernandes, C. I., \& Raposo, M. L. (2017). The effects of location on firm innovation capacity. Journal of the Knowledge Economy, 8(1), 77-96.

Financial Times (2020). "Business Education". Available at: Http://Rankings.Ft.Com/Businessschoolrankings/Rankings (accessed Sept.2020)

Filippetti, A., Frenz, M., \& Ietto-Gillies, G. (2011). Are innovation and internationalization related? An analysis of European countries. Industry and Innovation, 18(5), 437-459.

Guillotin, B. (2015). Internationalization and differentiation strategies: the case of American and European business schools. Available at SSRN 2771108.

Guillotin, B., \& Mangematin, V. (2015). Internationalization strategies of business schools: how flat is the world?. Thunderbird International Business Review, 57(5), 343-357.

Guillotin, B. (2018). Strategic internationalization through curriculum innovations and stakeholder engagement. Journal of International Education in Business.

Harrison, R. T., Leitch, C. M., \& Chia, R. (2007). Developing paradigmatic awareness in university business schools: The challenge for executive education. Academy of Management Learning \& Education, 6(3), 332-343. 
Haskins, M. E., Hicks, J. S., \& Centini, L. (2020). A codified executive education custom client engagement process. International Journal of Educational Management.

Hawawini, G. (2011). The internationalization of higher education institutions: A critical review and a radical proposal.

Hura, G. (2013). A new model for executive education. Journal of Executive Education, 2(2), 1.

Iandolo, S., \& Ferragina, A. M. (2019). Does persistence in internationalization and innovation influence firms' performance?. Journal of Economic Studies.

Juusola, K., Kettunen, K., \& Alajoutsijärvi, K. (2015). Accelerating the Americanization of management education: Five responses from business schools. Journal of Management Inquiry, 24(4), 347-369.

Juusola, K., \& Alajoutsijärvi, K. (2019). Revisiting Dubai's Business School Mania. Academy of Management Learning \& Education, 18(3), 484-492.

Kafouros, M.I., Buckley, P.J., Sharp, J.A. and Wang, C. (2008). The role of internationalization in explaining innovation performance. Technovation, 28(1-2), pp.63-74.

Kaltenecker, E. and Kahle-Piasecki, L., (2019). The impact of the Fourth Industrial Revolution in the Ownership, Location and Internalization advantages of firms: an exploratory study.

Lee Rodgers, J. and Nicewander, W.A., (1988). Thirteen ways to look at the correlation coefficient. The American Statistician, 42(1), pp.59-66.

Laud, R.L. and Johnson, M.S., (2013). Progress and regress in the MBA curriculum: The career and practice skills gap. Organization Management Journal, 10(1), pp.24-35.

Lilley, K., Barker, M. and Harris, N., (2014). Educating global citizens in business schools. Journal of International Education in Business.

Lloyd, F.R. and Newkirk, D., (2011). University-based executive education markets and trends. Unpublished manuscript. Retrieved from UNICON (University Consortium for Executive Education) http://192.185, 166, p.2011.

Lockhart, J.C., (2013). Executive education: can it be too good? Journal of Executive Education, 12(1), p.5.

Mayes, R.J., Bracey, P.S., Aguilar, M.G. and Allen, J.M., (2015). Identifying corporate social responsibility (CSR) curricula of leading US Executive MBA programs. In Handbook of research on business ethics and corporate responsibilities (pp. 179-195). IGI Global.

Narula, R., Asmussen, C. G., Chi, T., \& Kundu, S. K. (2019). Applying and advancing internalization theory: The multinational enterprise in the twenty-first century.

Navarro, P., (2008). The MBA core curricula of top-ranked US business schools: a study in failure?. Academy of management learning \& education, 7(1), pp.108-123.

Narayandas, D., (2007). Trends in executive education in business marketing. Journal of Business-toBusiness Marketing, 14(1), pp.23-30.

Roscoe, J.T., (1975). Fundamental research statistics for the behavioral sciences [by] John T. Roscoe.

Schlegelmilch, B.B., (2020). Why Business Schools Need Radical Innovations: Drivers and Development Trajectories. Journal of Marketing Education, p.0273475320922285.

Sharif, N. and Tang, H.H.H., (2014). New trends in innovation strategy at Chinese universities in Hong Kong and Shenzhen. International Journal of Technology Management, 65(1-4), pp.300-318.

Silvanto, S., Ryan, J. and Gupta, V., (2017). A study of the impact of business education on global career mobility. Journal of International Education in Business.

Stoten, D.W., (2018). Reforming the MBA: a survey of elite British universities. Journal of Management Development.

Tan, B. S., \& Ko, S. (2019). How relevant is the MBA: A revisit. Journal of Education for Business, 94(1), 64-69. 
Tsao, S.M. and Chen, G.Z., 2012. The impact of internationalization on performance and innovation: The moderating effects of ownership concentration. Asia Pacific Journal of Management, 29(3), pp.617642.

Vrontis, D. and Christofi, M., (2019). R\&D internationalization and innovation: A systematic review, integrative framework and future research directions. Journal of Business Research.

Walsh, A., \& Powell, P. (2020). Re-imagining the MBA: an arts-based approach. Higher Education Pedagogies, 5(1), 148-164.

Youssef, S. S., Bygholm, A., \& Jaeger, K. (2012, April). Issues in Internationalization of education: The case of a Danish Business School exporting a blended learning MBA program to developing countries. In Proceedings of the $8^{\text {th }}$ International Conference on Networked Learning 2012 (pp. 276283).

Zhu, C., (2015). Organisational culture and technology-enhanced innovation in higher education. Technology, Pedagogy and Education, 24(1), pp.65-79.

Zhou, N., \& Guillen, M. F. (2016). Categorizing the liability of foreignness: Ownership, location, and internalization-specific dimensions. Global Strategy Journal, 6(4), 309-329. 